\title{
Preliminary Study of Sars-Cov-2 Occurrence in Wastewater in the Czech Republic
}

\author{
Hana Mlejnkova ${ }^{1}$, Katerina Sovova ${ }^{2, *}$ (), Petra Vasickova ${ }^{3}$, Vera Ocenaskova ${ }^{1}$, Lucie Jasikova ${ }^{1}$ \\ and Eva Juranova ${ }^{1}$ (D) \\ 1 T. G. Masaryk Water Research Institute, Public Research Institution, Podbabska 2582/30, 16000 Prague, \\ Czech Republic; hana.mlejnkova@vuv.cz (H.M.); vera.ocenaskova@vuv.cz (V.O.); lucie.jasikova@vuv.cz (L.J.); \\ eva.juranova@vuv.cz (E.J.) \\ 2 T. G. Masaryk Water Research Institute, Public Research Institution, Brno Branch, Mojmirovo namesti 16, \\ 61200 Brno, Czech Republic \\ 3 Veterinary Research Institute, Public Research Institution, Hudcova 296/70, 62100 Brno, Czech Republic; \\ vasickova@vri.cz \\ * Correspondence: katerina.sovova@vuv.cz; Tel.: +420-541-211-397; Fax: +420-541-211-397
}

Received: 30 June 2020; Accepted: 29 July 2020; Published: 30 July 2020

\begin{abstract}
The virus SARS-CoV-2, which has caused the recent COVID-19 pandemic, may be present in the stools of COVID-19 patients. Therefore, we aimed to detect SARS-CoV-2 in wastewater for surveillance of SARS-CoV-2 in the population. Samples of untreated wastewater were collected from 33 wastewater treatment plants (WWTPs) of different sizes within the Czech Republic. SARS-CoV-2 RNA was concentrated from wastewater and viral RNA was determined using real-time reverse transcription polymerase chain reaction (RT-qPCR). SARS-CoV-2 RNA was detected in $11.6 \%$ of samples and more than $27.3 \%$ of WWTPs; in some of them, SARS-CoV-2 was detected repeatedly. Our preliminary results indicate that an epidemiology approach that focuses on the determination of SARS-CoV-2 in wastewater could be suitable for SARS-CoV-2 surveillance in the population.
\end{abstract}

Keywords: wastewater-based epidemiology; early warning system; virus; coronavirus; SARS-CoV-2; wastewater; epidemic; RT-qPCR

\section{Introduction}

Since the beginning of the year 2020, there has been significantly increased awareness of the existence of microorganisms that cause disease. One such representative group of viruses is SARS-CoV-2. This virus was able to spread a respiratory disease called COVID-19 to the level of a global pandemic in a very short period of time.

In the Czech Republic, the first case of COVID-19 was documented on 1 March 2020. The maximum number of concurrent cases to date of the epidemic was reached in the middle of April (11 April 2020) with 4651 COVID-19 infected persons. The overall number of infected persons at the end of this study in the middle of June (14 June 2020) was 10,064 (data provided by the Ministry of Health of the Czech Republic).

Coronaviruses, whose name was derived from their crown-like shape (corona in Latin), are enveloped, positive-sense RNA viruses. The genome of coronaviruses is encoded in a single strand of RNA with a positive polarity of approximately 30,000 bases, making these viruses the largest known RNA viruses with a non-segmented genome. Coronaviruses are known to cause respiratory and gastro-intestinal infections in animals and humans [1,2]. They are usually responsible for the common cold or mild respiratory infections; nevertheless, severe infections such as Severe Acute Respiratory Syndrome (SARS), Middle East Respiratory Syndrome (MERS), and most recently COVID-19 have also been described [3-8]. 
Coronaviruses are mainly transmitted through respiratory secretions. However, the RNA of SARS, MERS and even SARS-CoV-2 has been detected in stool and urine samples from infected persons [9-18]. Fecal excretion of the virus was found in approximately $50 \%$ of infected persons [9-18]. SARS-CoV-2 RNA has also been detected in the feces of COVID-19 patients exhibiting only mild or no symptoms, even long after they resolved and tested negative for SARS-CoV-2 RNA in respiratory secretions. Thus, viral shedding can last longer than shedding from the respiratory tract $[9,19,20]$. However, it is still unclear whether SARS-CoV-2 can be transmitted via the fecal-oral route.

The sources of SARS-CoV-2 in wastewater are mainly feces, respiratory secretions, contaminated personnel products (e.g., wet wipes, diapers, paper tissues), and urine [20-27]. The obtained data indicate that the number of viruses excreted in wastewater increases along with the number of infected persons in the population. The occurrence of SARS-CoV-2 RNA in wastewater has been described in several recent studies, for example from the Netherlands, Italy, USA, France, Spain, Australia, and Pakistan [24,28-34]. Research teams found SARS-CoV-2 RNA in wastewater soon after the epidemic occurred [24]. However, the most recent observation from Italy revealed that SARS-CoV-2 RNA was present in wastewater samples in December 2019, long before the country's first confirmed cases [35].

The viral load in feces and the detection limit of analyses are essential limiting factors for the success of SARS-CoV-2 monitoring in wastewater. Hata et al. [29] suggested that the limit of SARS-CoV-2 RNA detection in wastewater is roughly estimated as 2 copies $/ \mathrm{mL}$ using RT-qPCR, meaning that $6.0 \times 10^{10}$ copies per 100,000 inhabitants must be present in the sewer catchment area for the detection of SARS-CoV-2 RNA in wastewater when the daily wastewater quantity is $300 \mathrm{~L} /$ person/day [29].

Wastewater monitoring has been successfully used for tracking drug consumption, pharmaceutical use, water pollution, and antibiotic resistance [36-38]. However, through SARS-CoV-2 detection in wastewater, it is also possible to obtain unique epidemiological information on its occurrence in the population (presence, absence, and trends: increase, stagnation, decrease) [39-44]. A properly set up wastewater monitoring system enables outbreak monitoring and trend observations in the numbers of viral diseases of future periods and may be used as an early warning tool to set up a system for effective surveillance of disease spread.

In this study, we aimed to detect SARS-CoV-2 RNA in untreated wastewater samples in the Czech Republic. Observed data indicated the applicability of a wastewater monitoring approach for SARS-CoV-2 surveillance in the population.

\section{Materials and Methods}

\subsection{Wastewater Sampling}

From April to June 2020, untreated wastewater samples were collected weekly (weeks 17-25 in 2020) from inflow of 33 wastewater treatment plants (WWTPs) within the Czech Republic. WWTPs were chosen preferably in regions with higher prevalence of COVID-19. An overview of the selected WWTPs according to the population served is given in Table 1. WWTP catchments represented approximately $12.2 \%$ of the population of the Czech Republic.

Table 1. The overview of the selected WWTPs according to the population served.

\begin{tabular}{cc}
\hline $\begin{array}{c}\text { WWTP Capacity According to the Population } \\
\text { Served (Number of Inhabitants) }\end{array}$ & Number of WWTPs Involved in the Study \\
\hline$<2000$ & 2 \\
\hline $2000-10,000$ & 7 \\
\hline $10,000-100,000$ & 21 \\
\hline$>100,000$ & 3 \\
\hline
\end{tabular}


In total, 112 samples were taken by WWTP operators. Most samples were $24 \mathrm{~h}$ composite samples (time or flow dependent) of $500 \mathrm{~mL}$ and were collected from WWTP inflows. Immediately after sampling, samples were cooled and stored at $5 \pm 3{ }^{\circ} \mathrm{C}$ until analyzed. The analysis was performed within $48 \mathrm{~h}$ after sampling.

\subsection{Sample Concentration and RNA Extraction}

The wastewater concentration was conducted by direct flocculation [45] using beef extract solution (3.0\% w/v, pH 9.5; Sigma-Aldrich, St. Louis, USA) in glycine buffer (0.05 M). Briefly, $500 \mathrm{~mL}$ of the wastewater sample was acidified $(\mathrm{pH} 3.5 \pm 0.1)$ and $10 \mathrm{~mL}$ of beef extract flocculated by the addition of 1 and $0.1 \mathrm{M} \mathrm{HCl}$ (pH 3.5 to 3.0; a visible floc formed) was added. The suspension was stirred for $10 \mathrm{~h}$ to allow the viruses present to adsorb to the flocs and subsequently centrifuged at $10,000 \times g$ for $30 \mathrm{~min}$ at $4{ }^{\circ} \mathrm{C}$. The pellet was dissolved in $8 \mathrm{~mL}$ of phosphate-buffered saline (PBS) and RNA isolated with the NucliSENS ${ }^{\circledR}$ miniMAG ${ }^{\circledR}$ system (BioMérieux, Marcy l'Etoile, France) according to the manufacturer's instructions.

\subsection{Process Control Virus}

According to ISO 15216-2:2019 [46], the virus selected for use as a process control should provide similar morphological and physicochemical quality to the target virus and should be sufficiently distinct genetically that the detecting assay does not cross-react. Therefore, transmissible gastroenteritis coronavirus (TGEV, strain M42, Collection of zoopathogenic organisms, Veterinary Research Institute, p.r.i., Brno, the Czech Republic) from infected pigs was used as a process control virus (PCV) for the purposes of SARS-CoV-2 RNA detection in wastewater samples. Prior to any sample treatment, each sample was artificially contaminated with $5 \mu \mathrm{L}$ of TGEV (106 genome equivalents $(\mathrm{GE}) / \mu \mathrm{L})$ to verify the isolation of viral RNA. TGEV-specific RNA was detected using primers and probes adopted from the literature [47]. An internal amplification control was incorporated into the RT-qPCR assay [48].

\subsection{RT-qPCR Analysis}

The presence of SARS-CoV-2 RNA in wastewater was detected by real-time reverse transcription polymerase chain reaction (RT-qPCR) using EliGene COVID19 Basic A RT kit (Elizabeth Pharmacon, Brno, the Czech Republic) according to the manufacturer's instructions. The kit is applicable to RNA isolated from all relevant clinical specimens (nasopharyngeal swabs, saliva, sputum, serum, plasma, and feces), as well as to environmental samples (wastewater, etc.). Specificity of the assay targeting three parts of the SARS-CoV-2 genome is declared by the manufacturer. Each sample of isolated RNA was tested by RT-qPCR in duplicate. To reveal possible inhibition of the assay and thus avoid false negative results, undiluted and 10× diluted samples of extracted RNA were analyzed. RT-qPCR assays targeting SARS-CoV-2, as well as the TGEV genome, included internal amplification controls. Samples with a cycle quantification value $(\mathrm{Cq})<40$ were considered positive. Amplification and fluorescence detection were performed on a LightCycler 480 (Roche Molecular Diagnostics, Mannheim, Germany). The subsequent analysis was carried out using the "Fitpoint analysis" of the LightCycler 480 Software release 1.5.0 (version 1.5.0.39; Roche Molecular Diagnostics, Mannheim, Germany). The absolute quantification of TGEV (PCV, GE/500 mL) was completed on the basis of a calibration curve derived from a 10-fold diluted in vitro transcript [48]. Detection and quantification of TGEV (PCV), and calculation of processing efficiency was performed as previously described [49]. Samples with a processing efficiency $<1.0 \%$ were not considered for further analysis.

\section{Results}

In this study, wastewater samples from 33 WWTPs were collected and subjected to SARS-CoV-2 RNA detection. Out of all analyzed samples (112), 13 (11.6\%) were found to be positive. SARS-CoV-2 RNA positive samples were found at nine WWTPs. SARS-CoV-2 RNA-positive samples from three WWTPs were found repeatedly (twice and three times, respectively). Regions of the Czech Republic 
where SARS-CoV-2 RNA was detected in wastewater are identified in Figure 1. Prevalence of COVID-19 cases in those regions varied between 24 and 561 cases per 100,000 inhabitants (based on RT-qPCR detection of SARS-CoV-2 from respiratory secretions provided by authorized laboratories; data provided by the Ministry of Health of the Czech Republic).
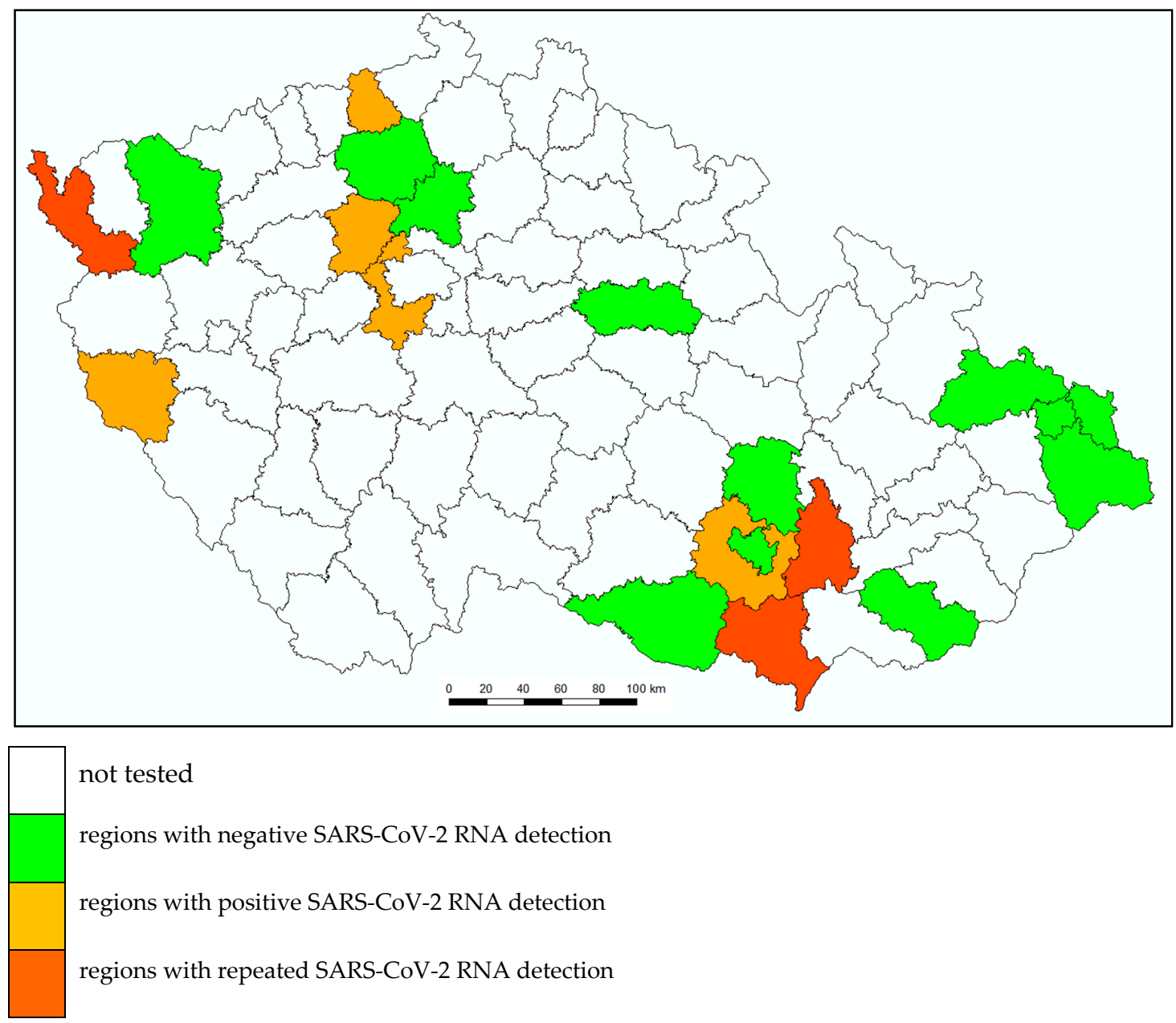

Figure 1. Regions of the Czech Republic where SARS-CoV-2 RNA was detected in wastewater.

Based on the detection and quantification of TGEV (PCV), the mean efficiency of whole wastewater sample analysis was $35.53 \%$ with a standard deviation of 13.04 . Cq ranging between 37 and 40 was achieved for seven (53.8\%) influent wastewater samples, a lower Cq of 34-37 was also observed (six samples; $46.2 \%$ ).

Table 2 shows a summary of the occurrence of positive wastewater samples and Cq.

Table 2. Results of SARS-CoV-2 RNA detection in wastewater samples obtained by EliGene COVID19 Basic A RT kit (Elizabeth Pharmacon, Brno, the Czech Republic). The results include processing efficiency calculated for each sample analyzed (\%).

\begin{tabular}{ccccccccccc}
\hline $\begin{array}{c}\text { WWTP } \\
\text { Code }\end{array}$ & $\begin{array}{c}\text { Size of } \\
\text { WWTP }\end{array}$ & Week 17 & Week 18 & Week 19 & Week 20 & Week 21 & Week 22 & Week 23 & Week 24 & Week 25 \\
\hline B1 & L & $-28.06 \%$ & $-23.52 \%$ & $-33.95 \%$ & $-39.59 \%$ & $-33.97 \%$ & $-31.27 \%$ & $-32.76 \%$ & & \\
\hline B2 & M & $-26.25 \%$ & $\begin{array}{c}+(36.53)^{*} \\
25.50 \%\end{array}$ & $\begin{array}{c}+(36.36)^{*} \\
25.28 \%\end{array}$ & $-35.51 \%$ & $-42.95 \%$ & $\begin{array}{c}+(38.77) \\
36.75 \%\end{array}$ & $-39.79 \%$ & $-39.48 \%$ & $-43.51 \%$ \\
\hline B3 & M & $-43.22 \%$ & $-46.72 \%$ & & & & & & \\
\hline B4 & M & $-46.92 \%$ & $-33.07 \%$ & & & & \\
\hline
\end{tabular}


Table 2. Cont.

\begin{tabular}{|c|c|c|c|c|c|c|c|c|c|c|}
\hline $\begin{array}{l}\text { WWTP } \\
\text { Code }\end{array}$ & $\begin{array}{l}\text { Size of } \\
\text { WWTP }\end{array}$ & Week 17 & Week 18 & Week 19 & Week 20 & Week 21 & Week 22 & Week 23 & Week 24 & Week 25 \\
\hline B5 & $S$ & & & $\begin{array}{c}+(39.62) \\
27.75 \%\end{array}$ & $\begin{array}{c}+(34.40)^{*} \\
24.17 \%\end{array}$ & $-33.10 \%$ & $-42.23 \%$ & $-31.58 \%$ & & \\
\hline $\mathrm{C} 1$ & $S$ & & & $-31.29 \%$ & $-24.16 \%$ & & & & & \\
\hline C2-A & \multirow{4}{*}{ M } & & & & & & $-41.38 \%$ & $-43.15 \%$ & & \\
\hline C2-B & & & & & & & $-47.95 \%$ & $-40.27 \%$ & & \\
\hline C2-E & & & & & & & $-46.90 \%$ & $-23.06 \%$ & & \\
\hline $\mathrm{C} 2-\mathrm{F}$ & & & & & & & $-30.12 \%$ & $-47.29 \%$ & & \\
\hline D1 & $S$ & & $-32.20 \%$ & $-26.92 \%$ & & & & & & \\
\hline D2 & M & & & & & $-29.49 \%$ & $\begin{array}{c}+(38.84)^{*} \\
23.27 \%\end{array}$ & $-29.82 \%$ & & \\
\hline $\mathrm{F}$ & M & & & & $-28.20 \%$ & & & $-37.01 \%$ & & \\
\hline $\mathrm{H} 1$ & $S$ & $-44.76 \%$ & $\begin{array}{l}+(37.19) \\
37.09 \%\end{array}$ & $-39.44 \%$ & $-46.59 \%$ & $-31.95 \%$ & $-26.63 \%$ & $-26.36 \%$ & & \\
\hline I & M & $-48.57 \%$ & $-42.40 \%$ & $-28.96 \%$ & & & & & & \\
\hline $\mathrm{K}$ & $\mathrm{M}$ & & & & & & & $-45.84 \%$ & & $-46.50 \%$ \\
\hline K1 & $\mathrm{M}$ & $-30.91 \%$ & $-39.92 \%$ & $-27.36 \%$ & $-34.46 \%$ & $-44.94 \%$ & $-23.71 \%$ & $-46.84 \%$ & & \\
\hline L1 & M & & & $-26.63 \%$ & $-31.48 \%$ & $-22.90 \%$ & & $-31.30 \%$ & & \\
\hline M1 & M & & & & $\begin{array}{c}+(36.59) \\
42.86 \%\end{array}$ & $-46.01 \%$ & $\begin{array}{l}+(39.35) \\
33.53 \%\end{array}$ & $-31.82 \%$ & & \\
\hline M2 & M & & & & & & $-41.92 \%$ & & & \\
\hline N1 & XS & & $-37.20 \%$ & $-24.92 \%$ & & & & & & \\
\hline $\mathrm{O}$ & M & & & & $-36.78 \%$ & & & $-25.42 \%$ & & \\
\hline OV & $\mathrm{L}$ & & & & & & & $-29.64 \%$ & & $-26.10 \%$ \\
\hline $\mathrm{P} 1$ & XS & $-35.13 \%$ & $\begin{array}{c}+(34.65) \\
44.05 \%\end{array}$ & $-39.52 \%$ & & & & & & \\
\hline P2-A & \multirow{2}{*}{$\mathrm{L}$} & & & & $-30.25 \%$ & & & $-34.68 \%$ & & \\
\hline P2-B & & & & & $-44.59 \%$ & & & & & \\
\hline $\mathrm{R} 1$ & $S$ & $-29.08 \%$ & $-26.92 \%$ & $-22.49 \%$ & & & & & & \\
\hline$S$ & $S$ & & & $\begin{array}{l}+(38.55) \\
33.40 \%\end{array}$ & $-46.83 \%$ & $-43.27 \%$ & $-25.95 \%$ & $-44.14 \%$ & & \\
\hline $\mathrm{T}$ & M & $-23.45 \%$ & $\begin{array}{c}+(34.97) \\
36.93 \%\end{array}$ & $-30.50 \%$ & $-33.10 \%$ & $-39.95 \%$ & & & & \\
\hline $\mathrm{T} 1$ & $\mathrm{M}$ & $-24.85 \%$ & $-40.09 \%$ & $-44.82 \%$ & & & & & & \\
\hline $\mathrm{U}$ & $\mathrm{M}$ & & & & $-46.58 \%$ & $-46.69 \%$ & & & & \\
\hline U1 & M & & & & & $-47.82 \%$ & & $-46.59 \%$ & & \\
\hline UB & M & & & & $-35.75 \%$ & $-36.88 \%$ & & & & \\
\hline $\mathrm{V}$ & $\mathrm{M}$ & & & $-34.75 \%$ & & & & & & \\
\hline V1 & M & & & & & & $\begin{array}{c}+(39.86) \\
46.68 \%\end{array}$ & $-45.51 \%$ & & \\
\hline $\mathrm{Z}$ & $S$ & $-28.77 \%$ & $-25.07 \%$ & $-28.91 \%$ & & & & & & \\
\hline $\mathrm{Z1}$ & $\mathrm{M}$ & & $-40.34 \%$ & $-44.84 \%$ & & & & & & \\
\hline
\end{tabular}

Size of WWTP according to population served: XS, <2000; S, 2000-10,000; M, 10,000-100,000; L, >100,000; +, positive SARS-CoV-2 RNA detection; -, negative SARS-CoV-2 RNA detection; * results originating from 10-fold diluted isolated RNA; Cq (cycle quantification value) is in brackets.

\section{Discussion}

In this study, we aimed to detect SARS-CoV-2 in wastewater to use this approach for the surveillance of SARS-CoV-2 in the population.

For this purpose, a procedure based on direct flocculation [45] with a bovine extract solution was used to concentrate the viruses in wastewater, and an RT-qPCR assay was employed to reveal the possible presence of SARS-CoV-2 RNA. Losses of target viruses can occur at all steps during sample processing. Therefore, each step of the analytical procedure should be monitored, and the level of virus 
recovery should be determined for each sample [46]. TGEV as a PCV was used and the level of process efficiency was consequently specified in each analyzed sample (mean $35.53 \%$ with a standard deviation of 13.04). Water samples contain substances that may inhibit RT-qPCR. To control the RT-qPCR of an individual sample, an RNA internal amplification control should be used to reveal inhibition of the assay and thus avoid false negative results. Therefore, a commercially available kit (EliGene COVID19 Basic A RT; Elizabeth Pharmacon, Brno, the Czech Republic) containing such a control was applied. To date, other methods using two-phase separation (PEG-dextran method; designed for poliovirus detection) or ultracentrifugation associated with WHO-recommended or "homemade" RT-qPCR have been reported $[24,30]$. Regardless, the present results provide evidence of the suitability and validity of the described procedure for wastewater analysis.

A total of 112 wastewater samples from WWTPs from 20 regions (out of 76) in the Czech Republic were analyzed and thus a large area was inspected. A positive signal was observed for only $11.6 \%$ of samples of untreated wastewater. The percentage is lower than expected. The mild course of the epidemic in the Czech Republic and decline in the number of infected inhabitants during the study may be reasons why such numbers were observed. Research in other countries (e.g., Spain, France, and the Netherlands) reported the detection of SARS-CoV-2 RNA, often with higher number of positive samples [24,28-34]. Positive samples were found even in areas with low prevalence of COVID-19 infections as described by Randazzo et al. [32]. For some of the WWTPs, there was only positive detection in one of the nine weeks analyzed even if the infectious process usually lasts more than one week. Several explanations of this finding can be mentioned: COVID-19-infected persons registered according to their permanent residence and cured at the other places, the occurrence of asymptomatic cases of COVID-19 with the virus excretion, inconsistent excretion of the virus with feces of COVID-19 patients, or different amounts of wastewater on the date of sampling.

Virus shedding in feces was confirmed by other studies [9-18] but it is still unclear whether the viral particles in wastewater are vital and infective. According to previous studies [50,51], the vitality of SARS-CoV-2 in wastewater does not seem to be significant. SARS-CoV-2 transmission via wastewater has not been observed, probably due to its poor stability in wastewater and sensitivity to disinfectants [8,9].

Wastewater monitoring of SARS-CoV-2 seems to be usable in wastewater-based epidemiology as a good monitoring and surveillance system for COVID-19 in the population. This approach can provide rapid and reliable information about the disease outbreaks and their trends in the population. It seems to be suitable for surveillance of mild, subclinical, or asymptomatic cases [25,40-44]. Our preliminary results confirmed the potential of this approach for use as an early warning tool for effective surveillance of the diseases spread. In the future, correlation of our results with the exact number of infected people in the monitored areas (i.e., delicate data from public health sector), wastewater dilution, and other factors (e.g., network size, rainfall) will be performed. After this evaluation, the applicability of this approach for the early warning system as a suitable complementary method to clinical testing will be assessed.

\section{Conclusions}

Our results confirmed the assumption of the presence of SARS-CoV-2 RNA in wastewater from the inflow of WWTPs, however, not to the expected extent. A final evaluation and interpretation of results will be performed after the correlation of all accessible data. The preliminary results of wastewater monitoring seem to be applicable as an early warning system for COVID-19 surveillance in the population.

Author Contributions: Conceptualization, V.O. and H.M.; Methodology, H.M., K.S., P.V., V.O., and E.J.; Formal Analysis, P.V.; Investigation, H.M., K.S., P.V., V.O., and E.J.; Resources, H.M., K.S., V.O., and E.J.; Data Curation, H.M., K.S., V.O., L.J., and E.J.; Writing-Original Draft Preparation, K.S.; Writing-Review \& Editing, H.M., K.S., V.O., L.J., E.J., and P.V.; Supervision, H.M.; Project Administration, E.J. and H.M.; Funding Acquisition, H.M. and V.O. All authors have read and agreed to the published version of the manuscript. 
Funding: This study was financially supported from Institutional funds for the development of the research organization TGM WRI, p.r.i., within the framework of the internal grant No. 3600.52.33/2020 and the project Clean Water-Healthy City-subproject Municipal Wastewater as a diagnostic medium of the capital city of Prague. The project was financed by the capital city of Prague within the Operational Program Prague-Growth Pole of the Czech Republic, CZ.07.1.02/0.0/0.0/16_040/0000378. At the Veterinary Research Institute, p.r.i., the work was supported by the Ministry of Agriculture of the Czech Republic, institutional support MZE-RO0518.

Conflicts of Interest: The authors declare no conflicts of interest.

\section{References}

1. Drexler, J.F.; Corman, M.V.; Drosten, C. Ecology, evolution and classification of bat coronaviruses in the aftermath of SARS. Antivir. Res. 2014, 101, 45-56. [CrossRef]

2. Chan, J.F.W.; Lau, S.K.P.; To, K.K.W.; Cheng, V.C.C.; Woo, P.C.Y.; Yuen, K.Y. Middle east respiratory syndrome coronavirus: Another zoonotic betacoronavirus casuing SARS-like disease. Clin. Microbiol. Rev. 2015, 28, 465-522. [CrossRef]

3. Chan, P.K.; Chan, M.C. Tracing the SARS-coronavirus. J. Thorac. Dis. 2013, 5, S118-S121. [CrossRef]

4. Ding, Y.; He, L.; Zhang, Q.; Huang, Z.; Che, X.; Hou, J.; Wang, H.; Shen, H.; Qiu, L.; Li, Z.; et al. Organ distribution of severe acute respiratory syndrome (SARS) associated coronavirus (SARS-CoV) in SARS patients: Implications for pathogenesis and virus transmission pathways. J. Pathol. 2004, 203, 622-630. [CrossRef]

5. Su, S.; Wong, G.; Shi, W.; Liu, J.; Lai, A.C.K.; Zhou, J.; Liu, W.; Bi, Y.; Gao, G.F. Epidemiology, genetic, recombination, and pathogenesis of coronaviruses. Trends Microbiol. 2016, 24, 490-502. [CrossRef] [PubMed]

6. De Wit, E.; Van Doremalen, N.; Falzarano, D.; Munster, V.J. SARS and MERS: Recent insights into emerging coronaviruses. Nat. Rev. Microbiol. 2016, 14, 523-534. [CrossRef] [PubMed]

7. Cui, J.; Li, F.; Shi, Z.L. Origin and evolution of pathogenic coronaviruses. Nat. Rev. Microbiol. 2019, 17, 181-192. [CrossRef]

8. Chin, A.W.H.; Chu, J.T.S.; Perera, M.R.A.; Hui, K.P.Y.; Yen, H.-L.; Chan, M.C.W.; Peiris, M.; Poon, L.L.M. Stability of SARS-CoV-2 in different environmental conditions. Lancet Microbe. 2020, 1, e10. [CrossRef]

9. Corman, V.M.; Albarrak, A.M.; Omrani, A.S.; Albarrak, M.M.; Farah, M.E.; Almasri, M.; Muth, D.; Sieberg, A.; Meyer, B.; Assiri, A.M.; et al. Viral shedding and antibody response in 37 patients with Middle East Respiratory Syndrome coronavirus infection. Clin. Infect. Dis. 2016, 62, 477-483. [CrossRef]

10. Miri, S.M.; Roozbeh, F.; Omranirad, A.; Alavian, S.M. Panic of Buying Toilet Papers: A Historical Memory or a horrible truth? Systematic review of gastrointestinal manifestations of COVID-19. Hepat. Mon. 2020, 20, e102729. [CrossRef]

11. Zhang, T.; Cui, X.; Zhao, X.; Wang, J.; Zheng, J.; Zheng, G.; Guo, W.; Cai, C.; He, S.; Xu, Y. Detectable SARS-CoV-2 viral RNA in feces of three children during recovery period of COVID-19 pneumonia. J. Med. Virol. 2020, 92, 909-914. [CrossRef] [PubMed]

12. Lo, I.L.; Lio, C.F.; Cheong, H.H.; Lei, C.I.; Cheong, T.H.; Zhong, X.; Tian, Y.; Sin, N.N. Evaluation of SARS-CoV-2 RNA shedding in clinical specimens and clinical characteristics of 10 patients with COVID-19 in Macau. Int. J. Biol. Sci. 2020, 16, 1698-1707. [CrossRef] [PubMed]

13. Tian, Y.; Rong, L.; Nian, W.; He, Y. Review article: Gastrointestinal features in COVID-19 and the possibility of faecal transmission. Aliment. Pharmacol. Ther. 2020, 51, 843-851. [CrossRef] [PubMed]

14. Hindson, J. COVID-19, Faecal-oral transmission? Nat. Rev. Gastroenterol. Hepatol. 2020, 17, 259. [CrossRef]

15. Yeo, C.; Kaushal, S.; Yeo, D. Enteric involvement of coronaviruses: Is faecal-oral transmission of SARS-CoV-2 possible? Lancet Gastroenterol. Hepatol. 2020, 5, 335-337. [CrossRef]

16. Xiao, F.; Tang, M.; Zheng, X.; Liu, Y.; Li, X.; Shan, H. Evidence for Gastrointestinal Infection of SARS-CoV-2. Gastroenterology 2020, 158, 1831-1833. [CrossRef]

17. Heller, L.; Mota, C.R.; Greco, D.B. COVID-19 faecal-oral transmission: Are we asking the right questions? Sci. Total Environ. 2020, 729, 138919-138922. [CrossRef]

18. Wang, X.; Zhou, Y.; Jiang, N.; Zhou, Q.; Ma, W.L. Persistence of intestinal SARS-CoV-2 infection in patients with COVID-19 leads to re-admission after pneumonia resolved. Int. J. Infect. Dis. 2020, 95, 433-435. [CrossRef] 
19. Xu, Y.; Li, X.; Zhu, B.; Liang, H.; Fang, C.; Gong, Y.; Guo, Q.; Sun, X.; Zhao, D.; Shen, J.; et al. Characteristics of pediatric SARS-CoV-2 infection and potential evidence for persistent fecal viral shedding. Nat. Med. 2020, 26, 502-505. [CrossRef]

20. Cao, Q.; Chen, Y.C.; Chen, C.L.; Chiu, C.H. SARS-CoV-2 infection in children: Transmission dynamics and clinical characteristics. J. Formos. Med. Assoc. 2020, 119, 670-673. [CrossRef] [PubMed]

21. Chen, N.; Zhou, M.; Dong, X.; Qu, J.; Gong, F.; Han, Y.; Qiu, Y.; Wang, J.; Liu, Y.; Wei, Y.; et al. Epidemiological and clinical characteristics of 99 cases of 2019 novel coronavirus pneumonia in Wuhan, China: A descriptive study. Lancet 2020, 395, 507-513. [CrossRef]

22. Sun, J.; Zhu, A.; Li, H.; Zheng, K.; Zhuang, Z.; Chen, Z.; Shi, Y.; Zhang, Z.; Chen, S.; Liu, X.; et al. Isolation of infectious SARS-CoV-2 from urine of a COVID-19 patient. Emerg. Microb. Infect. 2020, 9, 991-993. [CrossRef] [PubMed]

23. Holshue, M.L.; DeBolt, C.; Lindquist, S.; Lofy, K.H.; Wiesman, J.; Bruce, H.; Spitters, C.; Ericson, K.; Wilkerson, S.; Tural, A.; et al. First case of 2019 novel coronavirus in the United States. N. Engl. J. Med. 2020, 382, 929-936. [CrossRef]

24. Medema, G.; Heijnen, L.; Elsinga, G.; Italiaander, R.; Brouwer, A. Presence of SARS-Cronavirus-2 in sewage. Environ. Sci. Technol. Lett. 2020. [CrossRef]

25. Quilliam, R.S.; Weidmann, M.; Moresco, V.; Purshouse, H.; O’Hara, Z.; Oliver, D.M. COVID-19, The environmental implications of shedding SARS-CoV-2 in human faeces. Environ. Int. 2020, 140, 105790. [CrossRef]

26. Kitajima, M.; Ahmed, W.; Bibby, K.; Carducci, A.; Gerba, C.P.; Hamilton, K.A.; Haramoto, E.; Rose, J.B. SARS-CoV-2 in wastewater: State of the knowledge and research needs. Sci. Total Environ. 2020, 739, 139076. [CrossRef]

27. Amirian, E.S. Potential fecal transmission of SARS-CoV-2: Current evidence and implications for public health. Int. J. Infect. Dis. 2020, 95, 363-370. [CrossRef]

28. Ahmed, W.; Angel, N.; Edson, J.; Bibby, K.; Bivins, A.; O’Brien, J.W.; Choi, P.M.; Kitajima, M.; Simpson, S.L.; $\mathrm{Li}$, J.; et al. First confirmed detection of SARS-CoV-2 in untreated wastewater in Australia: A proof of concept for the wastewater surveillance of COVID-19 in the community. Sci. Total Environ. 2020, 728, 138764. [CrossRef]

29. Hata, A.; Honda, R. Potential sensitivity of wastewater monitoring for SARS-CoV-2: Comparison with Norovirus cases. Environ. Sci. Technol. 2020, 54, 6451-6452. [CrossRef]

30. La Rosa, G.; Iaconelli, M.; Mancini, P.; Bonanno Ferraro, G.; Veneri, C.; Bonadonna, L.; Lucentini, L.; Suffredini, E. First detection of SARS-COV-2 in untreated wastewaters in Italy. Sci. Total Environ. 2020, 736, 139652. [CrossRef]

31. Lodder, W.; Husman, A.M.D. SARS-CoV-2 in wastewater: Potential health risk, but also source data. Lancet Gastroenterol. 2020, 5, 533-534. [CrossRef]

32. Randazzo, W.; Truchado, P.; Cuevas-Ferrando, E.; Simón, P.; Allende, A.; Sánchez, G. SARS-CoV-2 RNA in wastewater anticipated COVID-19 occurrence in a low prevalence area. Water Res. 2020, 181, 115942. [CrossRef] [PubMed]

33. Sodre, F.F.; Brandao, C.C.S.; Vizzotto, C.S.; Maldaner, A.O. Wastewater-based epidemiology as a strategy for community monitoring, mapping of hotspots and early warning systems of Covid-19. Quim. Nova 2020, 43, 515-519. [CrossRef]

34. Mlejnková, H.; Očenášková, V.; Sovová, K.; Vašǐčková, P.; Juranová, E. Koronavirus SARS-CoV-2 v povrchových a odpadních vodách (Coronavirus SARS-CoV-2 in surface and wastewater). VTEI 2020, 2, 28-32. [CrossRef]

35. La Rosa, G.; Mancini, P.; Bonanno Ferraro, G.; Veneri, C.; Iaconelli, M.; Bonadonna, L.; Lucentini, L.; Suffredini, E. SARS-CoV-2 has been circulating in northern Italy since December 2019: Evidence from environmental monitoring. medRxiv 2020. [CrossRef]

36. Očenášková, V. Komunální odpadní voda jako diagnostické médium (Municipal wastewater as a diagnostic medium). VTEI 2018, 60, 28-30.

37. Gracia-Lor, E.; Castiglioni, S.; Bade, R.; Been, F.; Castrignanò, E.; Covaci, A.; González-Mariño, I.; Hapeshi, E.; Kasprzyk-Hordern, B.; Kinyua, J.; et al. Measuring biomarkers in wastewater as a new source of epidemiological information: Current state and future perspectives. Environ. Int. 2017, 99, 131-150. [CrossRef] 
38. Cacace, D.; Fatta-Kassinos, D.; Manaia, C.M.; Cytryn, E.; Kreuzinger, N.; Rizzo, L.; Karaolia, P.; Schwartz, T.; Alexander, J.; Merlin, C.; et al. Antibiotic resistance genes in treated wastewater and in the receiving water bodies: A pan-European survey of urban settings. Water Res. 2019, 162, 320-330. [CrossRef]

39. Daughton, C.G. Wasterwater surveillance for population-Wide Covid-19: The present and future. Sci. Total Environ. 2020, 736, 139631. [CrossRef]

40. Mao, K.; Zhang, K.; Du, W.; Ali, W.; Feng, X.; Zhang, H. The potential of wastewater-based epidemiology as surveillance and early warning of infectious disease outbreaks. Curr. Opin. Environ. Sci. Health 2020, 17, 1-7. [CrossRef]

41. Orive, G.; Lertxundi, U.; Barcelo, D. Early SARS-CoV-2 outbreak detection by sewage-based epidemiology. Sci. Total Environ. 2020, 732, 139298. [CrossRef] [PubMed]

42. Barcelo, D. An environmental and health perspective for COVID-19 outbreak: Meteorology and air quality influence, sewage epidemiology indicator, hospitals disinfection, drug therapies and recommendations. J. Environ. Chem. Eng. 2020, 8, 104006. [CrossRef] [PubMed]

43. Hart, O.E.; Halden, R.U. Computational analysis of SARS-CoV-2/COVID-19 surveillance by wastewater-based epidemiology locally and globally: Feasibility, economy, opportunities and challenges. Sci. Total Environ. 2020, 730, 138875. [CrossRef] [PubMed]

44. Sims, N.; Kasprzyk-Hordern, B. Future perspectives of wastewater-based epidemiology: Monitoring infectious disease spread and resistance to the community level. Environ. Int. 2020, 139, 105689. [CrossRef]

45. Calgua, B.; Rodriguez-Manzano, J.; Hundesa, A.; Suñen, E.; Calvo, M.; Bofill-Mas, S.; Girones, R. New methods for the concentration of viruses from urban sewage using quantitative PCR. J. Virol. Methods 2013, 187, 215-221. [CrossRef]

46. ISO 15216-2: 2019 Microbiology of the Food Chain-Horizontal Method for Determination of Hepatitis A Virus and Norovirus Using Real-Time RT-PCR-Part 2: Method for Qualitative Detection; Organization for Standardization: Geneva, Switzerland, 2019.

47. Vemulapalli, R.; Gulani, J.; Santrich, C. A real-time TaqMan RT-PCR assay with an internal amplification control for rapid detection of transmissible gastroenteritis virus in swine fecal samples. J. Virol. Methods 2009, 162, 231-235. [CrossRef]

48. Vasickova, P.; Kralik, P.; Slana, I.; Pavlik, I. Optimisation of a triplex real time RT-PCR for detection of hepatitis E virus RNA and validation on biological samples. J. Virol. Methods 2012, 180, 38-42. [CrossRef]

49. Mikel, P.; Vasickova, P.; Tesarik, R.; Malenovska, H.; Kulich, P.; Vesely, T.; Kralik, P. Preparation of MS2 phage-like particles and their use as potential process control viruses for detection and quantification of enteric RNA viruses in different matrices. Front. Microbiol. 2016, 7, 1911. [CrossRef]

50. Ye, Y.; Ellenberg, R.M.; Graham, K.E.; Wigginton, K.R. Survivability, partitioning, and recovery of enveloped viruses in untreated municipal wastewater. Environ. Sci. Technol. 2016, 50, 5077-5085. [CrossRef]

51. Casanova, L.; Rutala, W.A.; Weber, D.J.; Sobsey, M.D. Survival of surrogate coronaviruses in water. Water Res. 2009, 43, 1893-1898. [CrossRef]

(C) 2020 by the authors. Licensee MDPI, Basel, Switzerland. This article is an open access article distributed under the terms and conditions of the Creative Commons Attribution (CC BY) license (http://creativecommons.org/licenses/by/4.0/). 